\title{
Comparative Study of Engineering Properties of Four Selected Cowpea (Vigna unguiculata) Varieties
}

\author{
Idowu D.O. ${ }^{1}$, Oloyede C.T. ${ }^{2}$ \\ ${ }^{1,2}$ Department of Agricultural Engineering, Ladoke Akintola University of Technology, Ogbomoso, Oyo State, \\ Nigeria \\ Corresponding Author: Idowu D.O.
}

DOI: https://doi.org/10.52403/ijrr.20220309

\begin{abstract}
Poor mechanization of cowpea (Vigna unguiculata L. Walp.) in Nigeria is due to unavailability of handling machine due to large number of variations in engineering properties of the crop. To design a functioning machine for the mechanization of the crop, engineering properties of its local varieties is needed. The four local varieties selected are Small White, Big White, Drum and Milk cowpea. The selected engineering properties investigated are size, shape, weight, density, bulk density, angle of repose and coefficient of friction. The seeds were bought from Waso market in Ogbomoso, Oyo State Nigeria. The selected properties were measured using standard methods. The results of the experiments showed that; Mean Length; small white $(7.99 \mathrm{~mm})$, milk $(10.30 \mathrm{~mm})$, big white $(10.40 \mathrm{~mm})$ and drum $(10.71 \mathrm{~mm})$; Breadth; small white $(6.53 \mathrm{~mm})$, milk (7.37 $\mathrm{mm})$; big white $(7.60 \mathrm{~mm})$ and drum (7.98 $\mathrm{mm})$; Thickness; milk $(5.00 \mathrm{~mm})$; small white $(5.41 \mathrm{~mm})$, drum $(5.61 \mathrm{~mm})$, and big white $(5.92$ $\mathrm{mm})$; Unit weight; drum (0.63 g), small white $(0.64 \mathrm{~g})$, big white $(0.56 \mathrm{~g})$, and milk $(0.63 \mathrm{~g})$; Sphericity; milk (0.70), drum (0.74), big white $(0.78)$ and small white (0.82);Angle of repose, small white (26.01), big white (26.05), drum (24.16) and milk (27.52). The average values of static coefficient of friction on the different verities (mild steel, stainless and glass) were, small white $(0.45,0.44,0.42)$; big white $(0.45$, $0.44,0.44)$, milk $(0.44,0.44,0.43)$ and drum $(0.45,0.44$ and .044$)$ respectively. The results from this experiment showed that in the design and manufacturing of operating system for handling and processing of the crop, effect of
\end{abstract}

engineering properties of different cowpea varieties must be incorporated.

Keywords: Engineering properties, cowpea, design, processing equipment, manufacturing, verities

\subsection{INTRODUCTION}

Cowpea (Vigna unguiculata L. Walp.), is an annual legume which originated from Africa and is widely grown in Africa, Latin America, Southeast Asia. It is a very nutritious food crop which contains a reasonable amount of protein and carbohydrates [1]. The crop is widely consumed in tropical and sub-tropical areas of Africa, Latin America, and Southeast Asia and also in Southern United states [2]. Cowpea seed is a nutritious component in the human and animal diet. [3] reported that it contains $24.8 \%$ protein, $1.9 \%$ fat, $6.3 \%$ fiber, $63.6 \%$ carbohydrate, $0.00074 \%$ thiamine, $0.00042 \%$ riboflavin, and $0.00281 \%$ niacin.

The seed is a good nutritional supplement to cereals and an extender of animal proteins [4]. It has been reported that all the parts of the crop are useful $[5 ; 6]$. The seed plays a critical role in the lives of millions of people in the developing world [7].

It has been reported that Cowpea is a very important crop to the livelihoods of relatively poor people in less developed countries of the tropics, especially where animal protein is not easily available for the 
family [8]. The crop was referred to as a strategic culture for the promotion of food security and health of populations on all continents [9]. Cowpea is gaining more industrial relevance due to its potential as an ingredient in food formulation.

\section{MATERIALS AND METHOD}

\subsection{Selection of Materials}

Four local varieties of cowpea (Small white, Big white, Milk and Drum) were used in this study. They were sourced from popular Waso market in Ogbomoso, Oyo State Nigeria.

\subsection{Preparation of Materials}

All foreign materials such as dust, stones, chaff, immature and broken seeds as well as bad seeds were removed by winnowing and manual picking. Sample selection was randomized throughout the tests.

\subsubsection{Measurement of the Physical Properties}

The physical properties selected are measured using standard methods and has described below.

\subsubsection{Linear dimension}

50 seeds were selected at random and their linear dimensions determined. For each seed, three linear dimensions were measured i.e. length (L), width (W) and thickness (T), using a venire caliper (with accuracy of $0.01 \mathrm{~mm}$ ). Hence, measurements of all size indices were replicated 50 times.

\subsubsection{Sphericity}

The shape of the seed was expressed in terms of its sphericity index $(\phi)$. The Sphericity was determined using Equation 1 which was reported $[9,10]$ and adapted by $11]$.

$\phi=\frac{(L W T)^{1 / 3}}{L} \times 100$

\subsubsection{Geometry mean diameter $\left(G_{g}\right)$}

Geometry mean diameter $\left(G_{g}\right)$ were obtained for 50 seeds selected at random using Equation 2 which has been used by; $[9,10]$ and was adapted by [11].

$$
G_{g}=(L W T)^{1 / 3}
$$

\subsubsection{Determination of 1000 seed mass}

The mass of 1000 seeds were determined by using an electronic balance with accuracy of $0.001 \mathrm{~g}$. The measurement was replicated 5 times for 1000 seeds selected at random [12]. This method was adapted by [11].

\subsubsection{Determination of true and bulk densities}

The true density of the seed was determined by the water displacement technique [13; 11]. 10 randomly selected cowpea seeds from each of the fourvarieties were weighed and lowered into a graduated measuring cylinder containing $30 \mathrm{ml}$ of water. It was ensured that the seeds were submerged during immersion in water. The net volumetric water displacement was recorded. The true density, $\rho_{t}$ was then calculated using Equation 3 below:

$$
\rho_{t}=\mathrm{m} / \mathrm{v}
$$

Where $m$ is the mass of the seed in $\mathrm{kg}$ $\mathrm{v}$ is the volume of the seed in $\mathrm{m}^{3}$

For bulk density measurement, an empty cylindrical container of $1000 \mathrm{ml}$ volume was filled with the seeds at a height of about $15 \mathrm{~cm}$, striking the top of the level and then weighing the content, the bulk weight was then recorded. This was done in 10 replications. Using the equation above, the bulk density $\left(\rho_{b}\right)$ was then calculated for each of the replications.

\subsubsection{Measurement of the Mechanical Properties}

The mechanical properties determined in this study included the angle of repose and coefficient of friction. 

varieties.

\subsubsection{Determination of angle of repose}

The dynamic angle of repose or the emptying angle was determined using the method of [14] and [10]) as adopted by [11]. A regular cylinder of $100 \mathrm{~mm}$ diameter and $150 \mathrm{~mm}$ height was used in determining the angle of repose. A cylinder was placed on the surface, filled with the cowpea seeds and raised slowly until it forms a cone of seeds (Fig.1). This was replicated five times. The angle of repose was then calculated using Equation 4.

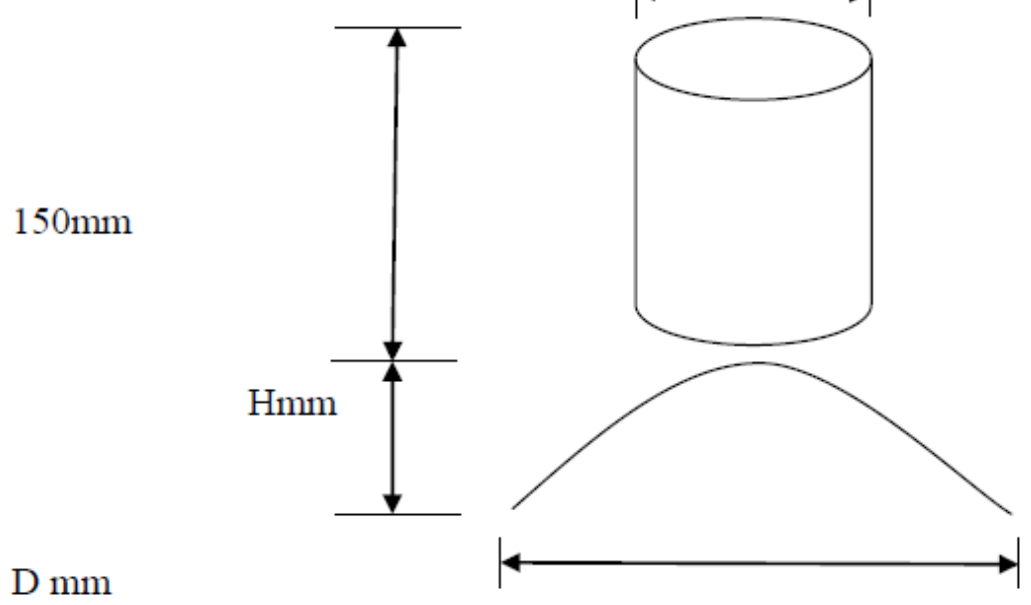

Fig. 1: Determination of angle of repose

$\phi=\tan ^{-1}\left(\frac{2 H}{D}\right)$

Where $\mathrm{H}$ is the height

$\mathrm{D}$ is the diameter

\subsubsection{Determination of coefficient of friction}

The coefficient of friction was determined on three different surfaces namely, galvanized steel, stainless steel and glass. These are the common materials used for handling and processing of grains and construction of storage and drying bins [15].

The experimental equipment consists of a frictionless pulley fitted on a frame, topless and bottomless plywood box of dimensions $250 \times 250 \times 90 \mathrm{~mm}$, loading pan, and test surfaces. The box was connected by means of a string, parallel to the surface of the material and passed over a frictionless pulley with a pan hanging from it. The box was placed on the test surface and filled with a known quantity of the seed and the box was raised gradually until the box and its containers started to move on the surface. The static coefficient of friction was then determined using Equation 5 as reported by $[14,10]$ and adapted by [11].

$$
U_{s}=F_{s} / W
$$

Where:

$$
\begin{aligned}
& \mathrm{U}_{\mathrm{s}}=\text { the static coefficient of friction } \\
& \mathrm{F}_{\mathrm{s}}=\text { the applied force } \\
& \mathrm{W}=\text { weight }
\end{aligned}
$$

\section{RESULT AND DISCUSSION \\ 3.0 Effect of Cowpea Varieties on the Physical Properties}

The results of the experiment on the physical properties of the selected varieties of cowpea is as presented in Table1.

\subsection{Size}

The results of the measurement on the effect of varieties on size of four selected cowpea variety was as presented in Table 1. Figure 1 present the size relationship of the varieties. The average values of the three principal dimensions namely, length, width and thickness were $7.99,6.5$ and $5.41 \mathrm{~mm}$ for Small white; $10.40,7.60$ and $5.92 \mathrm{~mm}$ for Big white, 10.71, 7.98, and 5.61 mm for Drum, 10.30, 
Idowu D.O. et.al. Comparative study of engineering properties of four selected cowpea (vigna unguiculata) varieties.

7.37, and $5.00 \mathrm{~mm}$ for Milk respectively. These results were in agreement with the report published by [16] who reported between $7.76-9.48 \mathrm{~mm}$ for the length of two varieties of cowpea studied (Sampea 7 and Tvx 3236). Although,[17] reported a slightly higher length (12.81-14.50 mm) for the variety of cowpea they used.

\begin{tabular}{|c|c|c|c|c|c|c|c|}
\hline & Properties & Variety & No & Mean & Minimum & Maximum & Standard deviation \\
\hline \multirow[t]{4}{*}{1} & Length & Small white & 100 & 7.99 & 7.25 & 9.23 & 0.67 \\
\hline & & Big white & 100 & 10.40 & 8.30 & 10.4 & 0.70 \\
\hline & & Drum & 100 & 10.71 & 8.30 & 11.45 & 1.47 \\
\hline & & Milk & 100 & 10.30 & 9.35 & 11.45 & 0.76 \\
\hline \multirow[t]{4}{*}{2} & Breadth & Small white & 100 & 6.53 & 6.00 & 7.25 & 0.51 \\
\hline & & Big white & 100 & 7.60 & 6.25 & 9.35 & 0.98 \\
\hline & & Drum & 100 & 7.98 & 7.00 & 8.33 & 0.55 \\
\hline & & Milk & 100 & 7.37 & 6.25 & 8.3 & 0.91 \\
\hline \multirow[t]{4}{*}{3} & Thickness & Small white & 100 & 5.41 & 5.18 & 6.25 & 0.43 \\
\hline & & Big white & 100 & 5.92 & 5.18 & 6.25 & 0.50 \\
\hline & & Drum & 100 & 5.61 & 4.18 & 6.23 & 0.72 \\
\hline & & Milk & 100 & 5.00 & 4.15 & 5.20 & 0.45 \\
\hline \multirow[t]{4}{*}{4} & Unit weight & Small white & 100 & 0.64 & 0.63 & 0.65 & 0.84 \\
\hline & & Big white & 100 & 0.56 & 0.55 & 0.56 & 0.31 \\
\hline & & Drum & 100 & 0.63 & 0.61 & 0.65 & 0.62 \\
\hline & & Milk & 100 & 0.63 & 0.62 & 0.64 & 0.96 \\
\hline \multirow[t]{4}{*}{5} & Sphericity & Small white & 100 & 0.82 & 0.76 & 0.89 & 0.05 \\
\hline & & Big white & 100 & 0.78 & 0.72 & 0.87 & 0.04 \\
\hline & & Drum & 100 & 0.74 & 0.62 & 0.84 & 0.06 \\
\hline & & Milk & 100 & 0.70 & 0.67 & 0.74 & 0.03 \\
\hline \multirow[t]{4}{*}{6} & Bulky Density & Small White & 10 & 0.95 & 0.91 & 0.99 & 0.04 \\
\hline & & Big White & 10 & 0.76 & 0.74 & 0.79 & 0.02 \\
\hline & & Drum & 10 & 0.83 & 0.80 & 0.86 & 0.02 \\
\hline & & Milk & 10 & 0.83 & 0.82 & 0.85 & 0.02 \\
\hline \multirow[t]{4}{*}{7} & Density (kg/m3) & Small White & 10 & 998.67 & 978.88 & 1011.23 & 23.45 \\
\hline & & Big White & 10 & 989.66 & 970.61 & 1001.25 & 24.55 \\
\hline & & Drum & 10 & 986.85 & 979.95 & 10101.55 & 13.98 \\
\hline & & Milk & 10 & 979.99 & 998.26 & 969.65 & 1.02 \\
\hline
\end{tabular}

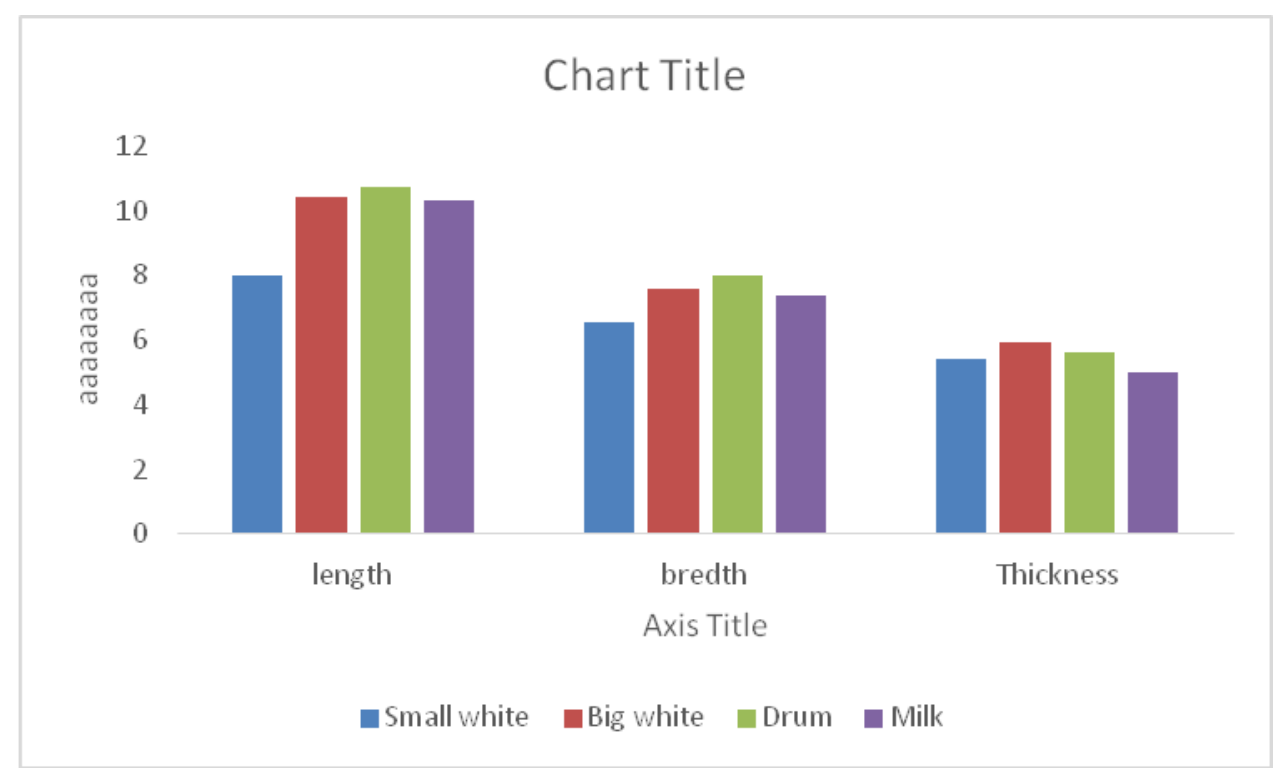

Fig.1: Effect of Varieties on Length, Breadth and Thickness

[18] reported a positive effect of seed size on germination and plant growth. The results were analyzed using single factor ANOVA. The analysis showed that the effect of varieties on length, breadth and thickness were significantly different $(\mathrm{p}>0.005)$.

\subsubsection{Implication of the results}

The different measure of the diameters is part of the essential information 

varieties.

needed for determination of terminal velocity of the grain. This terminal velocity determines the effectiveness of winnowing in selecting the velocity of the air blast for separation of chaff, dirt and other unwanted materials from clean grain in air screen grain cleaners. Frontal area and related diameters are essential for determination of terminal velocity, Reynolds number, drag coefficient and screen size selection.

\subsection{Shape \\ Sphericity}

The sphericity of the four varieties of cowpea investigated was found to be between 0.6 and 0.7 . These results were in agreement with the report presented by [19] who reported a variation between 0.66-0.78 for the two varieties of cowpea they studied. The results were analyzed using single factor ANOVA which shows that the sphericity is not significant.

\section{Implication of the results}

Shape of crop is important parameter which affects conveying characterizes of solid materials by air or water. The shape is also considered in calculating various cooling and heating loads of materials. It is also an important factor during the design of grading equipment and the selection of screen shape or size.

\section{Unit Weight}

The unit weight of the four varieties are Small white $(0.64 \mathrm{~g})$, Big white $(0.56 \mathrm{~g})$, Milk (0.63g and Drum (0.63g). These results were higher than the one reported by [19] who reported $0.33 \mathrm{~g}$ to $0.52 \mathrm{~g}$ and for the two varieties of cowpea and [20] that reported0.2777 for white, 0.15 for Reddishbrown cowpea. The results from the studied were analyzed using single factor ANOVA. The analysis showed that the unit weight was significantly different from each other ( $\mathrm{p}>0.005)$.

\section{Implication of the results}

The weight of crop is important parameter in the design of types and size of handling, processing, storage ban and equipment.

\section{Bulk density, and True density}

The values of bulk density measure are small white $(0.95 \mathrm{~g} / \mathrm{ml})$, big white $(0.76)$, drum (0.83) and milk (0.83) cowpea. The results were in the range found in literature. [2] and [1] reported between 0.72 and 0.82 for cowpea varieties studied.

\section{Implication}

The measurement of densities are essential for determination of terminal velocity of the grain.

Density and specific gravity are needed for calculating the thermal diffusivity in heat transfer operations to determine Renoids number in pneumatic and hydraulic handling of the crops.

\section{Effect of Varieties on Mechanical Properties}

The effect of varieties on the selected mechanical properties were as presented in Table 2 and as discussed below:

Table 2: Engineering Properties of Selected Cowpea Varieties

\begin{tabular}{|c|c|c|c|c|c|c|c|}
\hline & Properties & Variety & No & Mean & Mini & $\operatorname{Max}$ & Stan. devit. \\
\hline \multicolumn{8}{|c|}{ Angle of repose } \\
\hline \multirow[t]{4}{*}{1.} & & Small white & 10 & 26.01 & 24.75 & 26.7 & 1.09 \\
\hline & & Big white & 10 & 26.05 & 25.1 & 27.1 & 1.01 \\
\hline & & Drum & 10 & 24.16 & 23.46 & 24.61 & 0.61 \\
\hline & & Milk & 10 & 27.52 & 24.5 & 30.17 & 2.85 \\
\hline \multicolumn{8}{|c|}{ Coefficient of friction } \\
\hline \multirow[t]{4}{*}{2} & \multirow[t]{4}{*}{ Galvanized steel } & Small white & 10 & 0.45 & 0.42 & 0.45 & 0.02 \\
\hline & & Big white & 10 & 0.45 & 0.44 & 0.45 & 0.00 \\
\hline & & Drum & 10 & 0.44 & 0.45 & 0.45 & 0.00 \\
\hline & & Milk & 10 & 0.45 & 0.43 & 0.44 & 0.00 \\
\hline & \multirow{4}{*}{ Stainless Steel } & Small white & 10 & 0.44 & 0.42 & 0.45 & 0.02 \\
\hline & & Big white & 10 & 0.44 & 0.44 & 0.45 & 0.00 \\
\hline & & Drum & 10 & 0.44 & 0.45 & 0.45 & 0.00 \\
\hline & & Milk & 10 & 0.44 & 0.43 & 0.44 & 0.00 \\
\hline & \multirow[t]{4}{*}{ Glass } & Small white & 100 & 0.42 & 0.42 & 0.45 & 0.02 \\
\hline & & Big white & 100 & 0.44 & 0.44 & 0.45 & 0.00 \\
\hline & & Drum & 100 & 0.43 & 0.45 & 0.45 & 0.00 \\
\hline & & Milk & 100 & 0.44 & 0.43 & 0.44 & 0.00 \\
\hline
\end{tabular}



varieties.

\section{Angle of repose}

Table 2 shows the result of the experiment on the effect of varieties on angle of repose on selected varieties of cowpea. The results showed that the angle of repose range between 25.1 and $25.94^{0}$ for Big white; 24.75 and $26.7^{0}$ for Small white; 30.17 and $27.9^{0}$ for Milk and 24.4 and $24.61^{0}$ for Drum. This results are higher than the one published by [16] who reported between $\left(20.50^{\circ}\right.$ to $\left.21.05^{\circ}\right)$ for two varieties of cowpea (Sampea 7 and Tvx 3236) but in the range reported by [19] $\left(22.30^{\circ}\right.$ to $38.01^{\circ}$ for black-eye pea and brown beans).

\section{Implication of the Result}

The angle of repose is used in the design of handling and processing equipment. In a functional design of hopper and other equipment where free or gravity flow is required the angle of inclination of the plane to the horizontal must be at least about $10^{\circ}$ above the angle of repose of the material [21]. It also determines the maximum angle of a pile of grain in the horizontal plane, and is important in the filling of a flat storage facility when grain is not piled at a uniform bed depth [22].

\section{Coefficient of friction}

The coefficient of friction of cowpea for the four varieties ranges from 0.45 in Big white to 0.43 in Small white, from 0.45 in Drum to 0.44 in Milk. The result of the experiment shows that the coefficient of friction is different from each other. These results were in agreement with the report presented by [19] (black-eye pea and brown beans) who reported the static coefficient of friction on three different material surfaces to range between 0.3773 and 0.7089 on rubber, 0.3772 and 0.6630 on stainless steel, and 0.4177 and 0.6576 on galvanized steel. Though the results on the four varieties was not statistically significant (p.0.5) but when compared with the results published by other researches on cowpea the results on coefficient of frictions were significantly different at same level of significant.

\section{Implication of result}

The coefficient of friction is a very necessary engineering information in sizing motor requirements for grain transportation and handling. The coefficient of friction is used to determining the angle at which chutes must be positioned in order to achieve consistent flow of material through it [23].

\section{CONCLUSION}

Based on investigation conducted on the engineering properties of the four varieties of cowpea seeds namely Small white, Big white, Milk and Drum beans, the following conclusion were made:

The mean length, breadth, and thickness, for the four varieties of cowpea were in these range, $7.9-10.30 \mathrm{~mm}, 6.53$ $7.37 \mathrm{~mm}, 5.00-5.41 \mathrm{~mm}$. The unit weight, sphericity, bulk density, $0.76-0.95$ $\mathrm{kg} / \mathrm{m}^{3}$ angle of repose and coefficient of friction were in the range $0.64-0.63 \mathrm{~g}, 0.82$ - $0.70,26.01^{\circ}-27.52^{\circ}$ and $0.43-0.44^{\circ}$ respectively.

The success of any agricultural engineering design effort is determined largely by the availability of data on the engineering properties of the agricultural materials. The tests conducted on the four varieties of cowpea revealed some engineering properties that are useful for machine design from planting, harvesting, and handling and packaging. Results revealed that, there are significant differences in the engineering properties of the cowpea varieties selected.

\section{Acknowledgement: None}

\section{Conflict of Interest: None}

\section{Source of Funding: None}

\section{REFERENCES}

1. Saima Hamid, Sabeera Muzaffar, Idress Ahmed Wani Farooq Ahmad Masoodi. Mohd, Munaf Bhat Physical and cooking characteristics of two copear cultivars grown in template Indian climate. Jurnal 
of the Saudi Society of Agricultural Sciences, 2016, 15(2): 1- 20

2. Appiah F. Asibuo, J.Y, and Kumah P. Physicochemical and Functional Properties of Bean Flours of three Cowpea (Vegna unguiculata (L) Walp) Varieties in Ghana. African

Journal of food Science, 2011, 5 (2):100104.

3. Bressani R. H. Nutritive Value of Cowpea In. S.R Singh and R.O Raachie, Eds,. Cowpea Research, Production and Utilization, Wiley, Winchester, 1985, 353359.

4. Davis, K.S. Corn Milling, Processing and Generation of Corn-products, Technical Symposium, Minnesota Corn Growers Association. Minnesota Nutrition Conference, $\quad$ September 11, 2001.

5. Alemu, S.Cowpea (Vigna unguiculata (L.) Walp.) (Fabaceae) Landrace Diversity in southern Ethiopia [MSc Thesis], 2015. Addis Ababa University. [Google Scholar].

6. Alemu, M., Asfaw, Z., Woldu, Z., Fenta, B. A., \& Medvecky, B.Cowpea (Vigna unguiculata (L.) Walp.) (Fabaceae) Landrace Diversity in Northern Ethiopia. International Journal of Biodiversity and Conservation, 2016, 8(11), 297-

309. https://doi.org/10.5897/IJBC2016.09 46 [Crossref], [Google Scholar].

7. Carneiro da Silva, A., da Costa Santos, D., Lopes Teixeira Junior, D., Bento da Silva, P., Cavalcante Dos Santos, R., \& Siviero, A. Cowpea: A Strategic Legume Species for Food Security and Health. Legume Seed Nutraceutical Research, 2018, https://doi.org/10.5772/intechopen.79006.

8. Akpapunam M.A. and Sefa- Dedeh S. Jack Bean (Canavalia ensiformis) Nutrition Related Aspects and Needed Research. Journal of plant food Human Nutrition,1997, 10: 123-127.

9. Ozguven, M, Sekin, S., Gurbuz, B, Sekeroglu, N., Ayanoglu, F. andErken, S. Tutu tibbi ve aromatic bitkiler Uretimi ve ticareti TMMOB, 2005.

10. Sessiz A., Esgici $\mathrm{R}$ and Krizi. $\mathrm{K}$. Moisture-Dependent Physical Properties of Caper (capparis ssp.) Fruit. Journal of Food Engineering, 2007, 79: 1426-1431.

11. Idowu D.O. and Owolarafe, O.K. Effect of Moisture Content and Loading Orientation on Some Strength Properties Relevant in the Design of Snake Gourd (Trichosanthes cucumerina. L) Seed Handing Device. Int: CIGR Ejournal,2015, 17 (4): 337-345.

12. Mohsenin, N. N. physical properties of some plant and animal materials .New York, N.Y: Gordon and Breach Science Publishers, 1978.

13. Owolarafe, O.K., Olabige, M.T. and Faborode, M.O.Physical and mechanical properties of two varieties of fresh oil palm fruit. Journal of Food Engineering, 2007, 78, 1228 - 1237.

14. Amin, M.N., Hossain, M.A., and Roy, C. Effects of Moisture Content on Some Physical Properties of Lentil Seeds. Journal of Food Engineering, 2004, 65, $83-87$.

15. Baryeh, E.A. Physical Properties of Bambara Groundnut. Journal of Food Engineering, 2001, 47: 321-326.

16. Ogbonnaya Chukwu and Musa Olushola Sunmonu. Determination of Selected Engineering Properties of Cowpea Related to Design of Processing Machine, International Journal of Engineering and Technology, 2010, 2 (6): 373-378.

17. Davies R.M. Engineering Properties of Three Varieties of Melon Seeds as Potentials for Development of Melon Processing Machines, Advance Journal of Food Science and Technology, 2009, 2(1):63-66

18. Tumpa, K., Vidakovic, A., Drvodelic, D., Sango, M., Idzojtic, M., Perkovic,I., Poljak,IThe Effect of Seed size on Germination and Seedling Growth in Sweet Chestnut (Castanea sativa Mill.). Forests, 2021, 12: 858- 869. https://doi.org/10.3390/f12070858.

19. Ogunnigbo, C. O., D. A. Adetan, and O. F. Olusunmade. Effect of soaking time on some engineering properties of cowpea (Vigna unguiculata). Agricultural Engineering International: CIGR Journal, 2018, 20(1): 143-149. 
Idowu D.O. et.al. Comparative study of engineering properties of four selected cowpea (vigna unguiculata) varieties.

20. Gondwe, T.M., Alamu, E.O., E.O., Mdziniso, P., Maziya-Dixon., B. Cowpea (Vigna Unguiculata (L) wap) for Food Security: an Evaluation of End - User Traits of Improved Varieties in Swaziland. Scientific reports 9, 2019. https://doi.org/10.1038/s41598-01052360-w.

21. Maduako, J.N., Faborode, M.O. Some Physical Properties of Cocoa Pods in Relation to Primary Processing. Ife Journal of Technology,1990, 2(1):1-7.

22. Mohsenin, N. N. Physical Properties of Plant and AnimalMaterials. 2nd Ed. New
York: Gordon and breach Science Publishers, 1986.

23. Olajide, J.O and Igbeka, J.C. Some physical properties of groundnut kernel. Journal of Food Engineering,2003, 58: 201-204.

How to cite this article: Idowu D.O., Oloyede C.T. Comparative study of engineering properties of four selected cowpea (vigna unguiculata) varieties. International Journal of Research and Review. 2022; 9(3): 75-82. DOI: https://doi.org/10.52403/ijrr.20220309 